\title{
Johann Heinrich Schmelzer's Serenata for the Celebrations of Maria Antonia Habsburg's Birthday
}

\author{
Petr Slouka / slouka@lobkowicz.cz
}

The Lobkowicz Collections, o.p.s., Prague and Nelahozeves / Department of Musicology, Faculty of Arts, Masaryk University, Brno, CZ

\begin{abstract}
Several political and social incidents notably marked the latter part of 1670 es within the Habsburg monarchy. The most tragic was perhaps epidemy of the worst plague of modern times. The epidemy affected Vienna in 1679 and spread quickly throughout other countries. However, for the Czech countries there was a brief period, which was relatively and culturally favourable. Owing to the epidemy, the whole imperial court moved to Prague, which for several months became the seat of the Emperor. Emperor's and Empress Dowager's musicians moved to Prague with the court as well. In Prague these bands performed several secular and ecclesiastic dramatico-musical works including the first comic opera in Czech lands - La Patienza di Socrate con due mogli by Antonio Draghi. On 18 January 1680 the serenata Die sieben Alter stimmen zusammen by Johann Heinrich Schmelzer and Johann Albrecht Ruedolph was performed for the occasion of Archduchess Maria Antonia's birthday. Although it does not represent an extensive work and its storyline is not based on a complicated dramatical plot, the composition is remarkable for its unusual subject, and for the libretto in German. Therefore, the goal of this paper is to examine this composition and its performance, and also to update some findings from previous literature.
\end{abstract}

\section{Keywords}

Johann Heinrich Schmelzer, Maria Antonia Habsburg, Leopold I, Imperial court, Prague Castle, Kroměřǐ̌, festive serenatas 
In a general historical view, years 1679 and 1680 in the Habsburg Monarchy are usually seen rather in a negative light. Besides the ongoing riots against the Habsburgs in Hungary and being in increasingly imminent danger of a conflict with Turks, also the worst plague outbreak in modern age took place in this period. But in relation to culture or particularly to music, it can be seen as an important era with regard to the Czech lands. This outbreak of Black Death forced the imperial court to leave Vienna and move to Prague which therefore became a residence of the ruler for some time again. Two court bands (one of the Emperor and the second one of the Empress Dowager) had to move to Prague, too. They performed several secular and ecclesiastic dramatico-musical works there. $^{1}$

Performing operas, serenatas, oratorios and sepolcri in Prague Castle was intended for a narrow circle of court members and selected guests. ${ }^{2}$ The musical development in the Czech lands was therefore not significantly influenced by this era - also because of its short duration. ${ }^{3}$ But as for the number of dramatico-musical productions, this stay was the richest of the Czech musical history. It is also necessary to take into account liturgical operations related to the imperial court and its attendance at services in Prague temples and the presence of the court in the old-town Jesuit seminary when performing school dramas. ${ }^{4}$

Musicology paid greater attention to this period only in the last few decades while this topic has not been discussed comprehensively so far. The stay of the court of Emperor Leopold in Prague in 1679-1680 was briefly described in the works of Oscar Tauber ${ }^{5}$ and Emilián Trolda. ${ }^{6}$ A crucial work in this regard is still a monograph by Herbert Seifert ${ }^{7}$, also the diploma thesis of Marc Niubò which primarily focused on Draghi's oratorio L'Abelle di Boemia, ovvero S. Wenceslao and other works of this period which have obvious bohemian connotations ${ }^{8}$, and his two partial studies. ${ }^{9}$ We cannot skip the foreword

1 NIUBÒ, Marc. Leopold I. a hudba císařského dvora v Praze v letech 1679-1680. In Barokni Praha - barokni Čechie 1620-1740: sbornik př́spěvků z vědecké konference o fenoménu baroka v Čechách, Praha, Anežský klášter a Clam-Gallasũv palác, 24.-27. zárí 2001. Olga Fejtová et al. (eds.). Praha: Scriptorium, 2004, p. 102-105.

2 NIUBÒ, Marc. Leopold I. a hudba císařského dvora v Praze v letech 1679-1680, op. cit., p. 101-102. See also SEIFERT, Herbert. Die Oper am Wiener Kaiserhof im 17. Jahrhundert. Tutzing: Verlegt bei Hans Schneider, 1985 , p. 89.

3 For more information on this issue see SEHNAL, Jiří. Pobělohorská doba (1620-1740). In Hudba v českých dějinách: od středověku do nové doby. Jaromír Černý et al. (eds.). Praha: Horizont, 1983, p. 178 and VOLEK, Tomislav. Die Bedeutung der italienischen Oper für das böhmische Barock. Mozart, die Italienische Oper des 18. Jahrhunderts und die musikalische Leben im Königreich Böhmen. Bd. II. Wien: Hollitzer Verlag, 2016, p. 98.

4 NIUBÒ, Marc. Leopold I. a hudba císařského dvora v Praze v letech 1679-1680, op. cit., p. 102-105.

5 TAUBER, Oscar. Geschichte des Prager theaters. Von den anfa "ngen des schauspielwesens bis auf die neueste zeit. Prag: K.K. Hofbuchdruckerei A. Haase, 1883, p. 39-40.

6 TROLDA, Emilián. Česká církevní hudba v období generálbasu. Cyril, 1934, LX, p. 58-59.

7 SEIFERT, op. cit., p. 101-102.

8 NIUBÒ, Marc. Císařský dvưr v Praze v letech 1679-80 a oratorium o svatém Václavovi. Diploma thesis. Praha: FFUK, 2000.

9 Ibidem, p. 95-131 and NIUBÒ, Marc. Le cappelle imperiali e la stagione praghese 1679/80. In „Il nuovo Cario, il divin Orfeo. "Antonio Draghi da Rimini a Vienna. Emilio Sala - Davide Daolmi (eds.). Lucca: Lim, 2000, p. 291-318. 
of the edition of Draghi's "Prague" oratorio called Jepthe the author of which is Angela Romagnoli ${ }^{10}$ as well as her valuable study on Draghi's Prague carnival opera. ${ }^{11}$

The imperial court's stay in Prague is said to be between September 1679 to May 1680. During this period, three serenatas as homages could be heard in the Prague castle (and the fourth in Pardubice), two operas and at least eight ecclesiastical dramaticomusical works - oratorios and sepolcri. ${ }^{12}$ Due to the critical situation and the increase in the number of celebrated days, those were always one-act pieces with adapted stage requirements. ${ }^{13}$ The first celebration which was complemented with a serenata was on the occasion of the birthday of Leopold's only surviving daughter from his first marriage - Maria Antonia (1669-1692). Its name was Die sieben Alter stimmen zusammen. ${ }^{14}$

The fact that no researcher has been interested in this piece so far is understandable because a printed libretto for this work was not preserved and only a particell (a short score) is available as for the music. ${ }^{15}$ The interesting thing is the language of the libretto and the fact that it is one of only few Schmelzer's dramatico-musical pieces. We can see some mentions of Die sieben Alter quite often in literature but those are usually - with only one exception - really short references. The oldest mention was found in Köchel's monograph which contains the list of dramatico-musical works performed at the imperial court between 1631 and $1710 .{ }^{16}$ The studied serenata is incorrectly described as a serenata to celebrate the birthday of archduchess Maria Anna (1634-1696). Also the comment that the librettist is unknown is not correct. His name is right at the title page of the particell of this piece to which Köchel refers. ${ }^{17}$ The serenata is also mentioned in the list of dramatic productions by Alexander von Weilen. But there is no further information about it. ${ }^{18}$ Few more details on the serenata are provided in the publication by Franz Hadamowsky. Besides the purpose of it, he also mentions the librettist but incorrectly mentions Anton Andreas Schmelzer (1653-1701) as the author of the music. ${ }^{19}$ But the

10 ROMAGNOLI, Angela ed. Antonio Draghi: Jephte. Praha: Koniasch Latin Press, 2000.

11 ROMAGNOLI, Angela. Galline, „Specolazioni“ e pene d'amore ossia La patienza di Socrate con due mogli di Minato e Draghi. In „Il nuovo Cario, il divin Orfeo. “ Antonio Draghi da Rimini a Vienna. Emilio Sala Davide Daolmi (eds.). Lucca: Lim, 2000, p. 171-223.

12 SEIFERT, op. cit., p. 497-500.

13 For more information about dramatico-musical operation at the court of Leopold I see SLOUKA, Petr. Hudebnědramatický provoz na dvoře císaře Leopolda I. In Koně v piškotech. Slavnosti na dvoře císaře Leopolda I. Kateřina Fajtlová - Miroslav Kindl (eds.). Olomouc: Muzeum umění Olomouc, 2017, p. 20-28.

14 A-Wn, Sig. Mus. Hs. 18898 Mus. The original title is Die ßiben Alter stimben zu ßamben anwintschent dem geburtß tag Ihro Durchleicht der Ertzherzogin Maria Antonia in einen vorbilt der ßonnen.

15 More information on scores from the so-called Bibliotheca Cubicularis in GMEINER, Josef. Die „Schlafkammerbibliothek“ Kaiser Leopolds I. In Biblos. 43, (3-4). Wien: Biblos, 1994, p. 199-212.

16 KÖCHEL, Ludwig. J. J. Fux. Hofcompositor und Hofkapellmeister der Kaiser Leopold I., Josef I. und Karl VI. von 1698 bis 1740. Wien: A. Hölder, 1872, Appendix VIII.

17 KÖCHEL, op. cit., p. 502.

18 WEILEN, Alexander von. Die vom Jahre 1629 bis zum Jahre 1740 am Wiener Hofe zur Aufführung gelangten Werke theatralischen Charakters und Oratorien. Wien: A. Hasse, 1901, p. 27.

19 HADAMOWSKY, Franz. Barocktheater am Wiener Kaiserhof 1625-1740. Mit einem Spielplan. In Jahrbuch der Gesellschaft für Wiener Theaterforschung. Wien: A. Sexl, 1952, p. 82. 
name of Johann Heinrich (1620/23-1680), the father of Anton Andreas, is mentioned in the particell. The interesting piece of information is the place where the serenata was performed, which supposed to be - according Hadamowsky - the palace of the supreme burgrave, Ignác Bořita of Martinice (1614-1685) on 21 January. ${ }^{20}$ Here refers he to an entry in Relationis Historicae Semestralis Autumnalis Continuatio. ${ }^{21}$ The piece is shortly mentioned in Seifert's monograph Die Oper am Wiener Kaiserhof im 17. Jahrhundert. ${ }^{22}$ The most detailed information about the work so far can be found in a dissertation by Ulrike Hofmann where she called Die sieben Alter the first serenata in German from the imperial court while she did not take into account Schmelzer's serenata Hercules und Onfale, stored in archiepiscopal music collection in Kroměříž castle. But the author incorrectly wrote that it was performed in Vienna. ${ }^{23}$

Die sieben Alter was performed in the evening of 18 January on the day of the birthday of archduchess Maria Antonia which is proven in a letter by marquis Pier Antonio Gerini. ${ }^{24}$ And the same letter also mentions the place of performance of the piece: $e$ la sera alle Sue stanze. In this regard, it is useful to mention that Hadamowsky's hypothesis was that the supreme burgrave Bernard Ignác Bořita of Martinice ordered the serenata. So the composition should have been performed in his palace. But Hadamowsky did not differentiate between two pieces devoted to the archduchess. The serenata we are interested in was really performed on 18 January because the date is written on the title page of the particell. Gerini mentions Thursday in his letter which corresponds to 18 January in 1680. The second performance called comödie in literature is mentioned in the memoirs of the Knights of the Cross with the Red Star prior Jiří Ignác Pospíchal who also mentions that Zuzana Polyxena of Martinice requested a descantist of the mentioned order for the performance of the comedy. ${ }^{25}$ The play probably yielded success as the already mentioned Relationis Historicae from Frankfurt informed about it and stated the date of the performance as 21 January which is a day after Guerini's letter was supposedly written. So the play which was performed in the palace in Martinice was probably a different production.

Die sieben Alter is not a very extensive one-act secular dramatico-musical composition with a total of 21 characters. Its main purpose is to celebrate the archduchess for the occasion of her birthday and to wish her a prosperous future.

\footnotetext{
20 HADAMOWSKY, op. cit., p. 82.

21 LAUTENBACH, Conrad - Sigmund LATOMUS. Relationis Historicae Semestralis Autumnalis Continuatio [...]. Tom. 1680. Vol. 3/2. Frankfurt am Main, 1682, p. 3.

22 SEIFERT, op. cit., p. 498.

23 HOFMANN, Ulrike. Die Serenata am Hofe Kaiser Leopold I. 1658-1705. Dissertation thesis. Wien: Universität Wien, 1975, p. 150-154.

24 The letter can be found in SEIFERT, op. cit., p. 779.

25 REZEK, Antonín. Paměti generála řádu křižovnického Jiřího Pospíchala z let 1661-1680. In Zprávy o zasedáni Králouské české společnosti nauk 1880. Praha: Královská česká společnost nauk, 1881, p. 148.
} 
Table: Die sieben Alter - characters

\begin{tabular}{|l|l|l|}
\hline Character (German) & \multicolumn{1}{|c|}{ Character (English) } & Type of voice \\
\hline Kindheit & Childhood & Soprano \\
\hline Jugend & Youth & Alto \\
\hline Das Manbahre Alter & Adulthood & Alto \\
\hline Das Angesehnte Alter & Foreseeing Age & Alto \\
\hline Das Instehente Alter & Future Age & Tenor \\
\hline Das Abgesehnte Alter & Ending Age & Tenor \\
\hline Das Erlebte Alter & Passed Age & Bass \\
\hline Die Zeit & Time & Bass \\
\hline Die Tugent & Virtue & Alto \\
\hline Die Witz & Wits & Soprano \\
\hline Der Verstant & Wisdom & Tenor \\
\hline Der Schutzgott & Protective God & Tenor \\
\hline Fama & Fame & Soprano \\
\hline Juno & Juno & Soprano \\
\hline Diana & Diana & Soprano \\
\hline Pallas & Minerva & Alto \\
\hline Apollo & Apollo & Alto \\
\hline 4 Mußen & 4 Muses & S, A, T, B (sic!) \\
\hline
\end{tabular}

The main element which differentiates this piece from more demanding in terms of production, dramatic but also one-act pieces of congratulations which are called festa teatrale is that it lacks a more complex plot. Neither scores nor printed librettos do not refer to the production of the piece. But with the regard to current knowledge of baroque acting which does not require a lot of space and uses particularly the gestures to express emotions, allegoric costumes and attributes, it was probably a semi-staged costumed performance. Besides the names of the individual characters, a proof can also be found in the texts of the serenatas themselves because they often require an action on the stage or some specific subject on the stage. Chain of congratulations and highlighting the virtues of the person celebrating birthday is the main topic of Die sieben Alter and other serenatas not only from the stay of the imperial court in Prague.

As the title of the serenata Die sieben Alter suggests, the main characters embody seven stages of human life. Allegories of time, reason, virtue, wits and the deity and Muse join them. This unusual theme presents a noticeable skilfulness in writing similar texts or their profound knowledge. The author of the libretto was poet laureate Johann Albrecht Ruedolf (Rudolph). The librettist's name is added to the title page of the particell of the serenata. We have almost no information about the life of this author. ${ }^{26}$ Similar standpoint was taken by Irmgard Scheitler. She writes about Ruedolf as the author of texts for sepolcri of Leopold I and observes that his name is known only from the notes on scores

26 SLOUKA, Petr. Německojazyčné holdovací serenaty Johanna Heinricha Schmelzera. In Cantantibus organis: hudebni kultura raného novověku ve středoevropských souvislostech: ad honorem Jiři Sehnal. Brno: Moravská zemská knihovna v Brně, 2016, p. 65. 
and librettos. ${ }^{27}$ Johann Willibald Nagel describes Ruedolf further as a poet laureate while he points out the duties of German poet laureates which were mainly translations. Their names, contrary to those of Italian poet laureates, were forgotten. ${ }^{28}$ Thanks to our own research of the printed librettors stored in Österreichische Nationalbibliothek and other institutions, this claim can be confirmed. More intensive activity in German translations and the creation of original German texts can be seen in 1670s and 1680s. Ruedolph is, thanks to his authorship of the librettos for the serenata Die sieben Alter and three sepolcri, the only poet laureate of Leopold I from the given period for which we have his own production documented. He can therefore be a potential author of anonymous German texts, e. g. the serenata Hercules und Onfale.

The librettist wrote the text based on the Ptolemy's division of human life into seven stages. Each stage of the human life is associated with a planet in this Ptolemy's theory the Moon, Mercury, Venus, Sun, Mars, Jupiter and Saturn. Ruedolf chose quite flowery names for the seven stages in the libretto. He partly refers to planets personified by the deity - Apollo, Diana or associates some stages with certain virtues. But the purpose of the work prevails over complex philosophical disputations which could arise from the topic. The text of this one-act serenata which praises the celebrating archduchess consists of the speeches of stages and virtues to the archduchess and to one another. During the speeches, the goddesses and Apollon come to the stage; the final ensemble is presented by four Muses. The whole serenata is introduced by a choir of seven personified stages. It appeals to trumpets and kettledrums to start playing ceremonially. The childhood then praises the beauty of the archduchess and puts her above Venus. The time will preserve this beauty forever. All characters promise they will follow the archduchess and they will be loyal to her. Other goddesses come. Muses pay tribute to the archduchess in the end. ${ }^{29}$ The opera pieces from Leopold's era are characteristic for its complex and indigenous allegories which mostly refer to current political events. But they are not used very much in this serenata with the comparison to the pieces intended for the emperor or empresses.

Unlike for the libretto, we do not have the whole piece at hand regarding music. Musical recording is significantly reduced which makes a detailed analysis of the piece and also the possibility to evaluate Schmelzer's compositional style in one of his last works almost impossible. Similarly as for Hercules und Onfale, Schmelzer chose a quite simple style of setting Ruedolf's libretto to music which seems to be deliberate and typical for the works dedicated to Maria Antonia (judging on the basis of the comparison with Schmelzer's sepolcri in German). All 12 arias and the final ensemble are strophic songs

27 SCHEITLER, Irmgard. Deutschsprachige Oratorienlibreti von den Anfangen bis 1703. In Beiträge zur Geschichte der Kirchenmusik. Ulrich Konrad (eds.), Bd. 12., München: Görres-Gesellschaft, 2005, p. 247, 251, 256-259.

28 NAGEL, Johann Willibald - ZEIDLER, Jakob. Deutsch-österreichische Literaturgeschichte. Bd. 1., Wien: Fromme, 1889, p. 696 .

29 HOFMANN, op. cit., p. 150-151. 
most often of $\mathrm{AA}^{\prime}$ or $\mathrm{AB}$ pattern and have a distinctive ditty and dancing nature at the expense of the strict implementation of musical-rhetorical figures. The text is set into music syllabically.

Diana

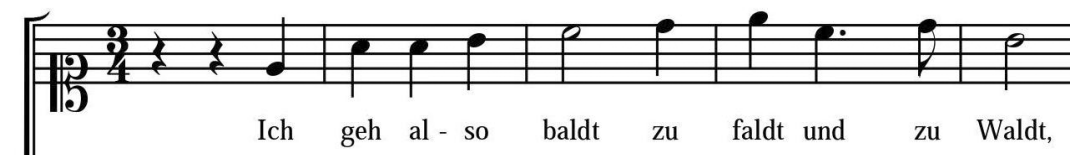

[Basso]

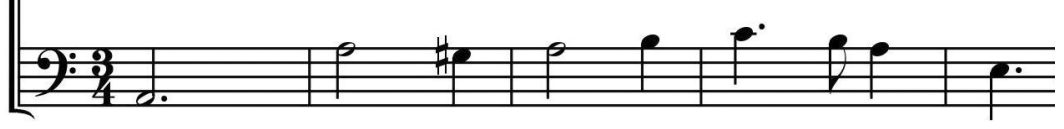

Ex. 1 Beginning of Diana's aria - typical Schmelzer's setting the dramatic text to music.

The serenata contains two arias with a solo instrument - a violin. Most specifically of the Forthcoming stage "Diana nim gschwind die Jaghundt" and of Apollo "Ihr Musen so eillet". The form of instrumental ritornellos is not known due to the reduced recording - they are always indicated with introductory bars of a high melodious voice with a written part for bass. The same can be said about the introductory choir. The piece also lacks the introductory Sinfonia including other potential instrumental pieces or ballets to which there is no reference. Thanks to two Schmelzer's serenatas that remain preserved in whole, we can assume that Schmelzer also used orchestral setting for five voices. ${ }^{30}$ The recitatives (which are often in the form of dialogues) ensure that the piece develops the story quickly. The dramatic character of recitatives is supported by the alternation of solos and ensembles and contrasts in pace.

Also, the performers are unknown. A whole range of singers and musicians was available during the stay of the court in Prague and their names are known thanks to the so-called Quartierbuch from 1680. ${ }^{31}$ Some names of Italian singers are known also thanks to handwritten notes on the Venetian specimen of the libretto to Draghi's Oratorio di Santa Cecilia..$^{32}$ The attention was brought to it in the preface of the edition of Draghi's oratorio called Jephte by Angela Romagnoli. ${ }^{33}$ But it is unlikely that the Italian singers would perform the piece with German texts. A clue for the identification of at least several singers could be again in this case the letter by Piere Antonio Gerini. Gerini states: una Serenata, alla quale intervenne la M[aes]tà dell'Imperatore, e le due Imperatrici. If intervenne means to actively participate in this case, three participants would be known (the emperor and both empresses). This claim would support the hypothesis about the

30 A-Wn, Sig. Mus. Hs. 16913 Mus. and CZ-Kra, Sig. A 928.

31 NIUBÒ, Marc. Císařský dvior v Praze v letech 1679-80 a oratorium o svatém Václavovi, op. cit., 2000, p. 38, compare with LEIBNITZ, Thomas. Die Musik der Kaiser im Spiegel der Wiener Hofmusikkapelle. In Spettacolo Barocco! Triumph des Theaters. Andrea Sommer-Mathis - Daniela Franke - Rudi Risatti (eds.). Wien: Michael Imhof Verlag, 2016, p. 121, 126-127.

32 I-Vnm, Sig. Misc. 2482.2

33 ROMAGNOLI, Angela ed. Antonio Draghi: Jephte, op. cit., p. I-XXII. 
participation of the members of the imperial court in German serenatas and it would also partly explain why the singing parts were not highly demanding.

The serenata Die sieben Alter is formally not distinctive from the production of congratulations of this period. A detailed learning of it is prevented by the fact that the sheet music which was preserved is not sufficient and the printed libretto is not available. Despite that, a thorough study of the piece and the sources related to it helps to find out some other important links, particularly about Schmelzer's production and the stay of the imperial court in Prague in 1679-1680 and it also contributes to a complex understanding of the musical operation at the imperial court in the second half of the $17^{\text {th }}$ century. Its contribution is also evident with regard to the text because it is one of a few serenatas in German from the imperial court. Last but not least, it is one of the oldest dramatico-musical pieces of the type of opera which was performed in our lands and we cannot overlook the fact that it is an important piece of Czech music history.

\section{Bibliography}

GMEINER, Josef. Die „Schlafkammerbibliothek“ Kaiser Leopolds I. In Biblos, 43, (3-4). Wien: Biblos, 1994.

HADAMOWSKY, Franz. Barocktheater am Wiener Kaiserhof 1625-1740. Mit einem Spielplan. In Jahrbuch der Gesellschaft für Wiener Theaterforschung. Wien: A. Sexl, 1952.

HOFMANN, Ulrike. Die Serenata am Hofe Kaiser Leopold I. 1658-1705. Dissertation thesis. Wien: Universität Wien, 1975.

KÖCHEL, Ludwig. J. J. Fux. Hofcompositor und Hofkapellmeister der Kaiser Leopold I., Josef I. und Karl VI. von 1698 bis 1740. Wien: A. Hölder, 1872.

LAUTENBACH, Conrad - Sigmund LATOMUS. Relationis Historicae Semestralis Autumnalis Continuatio [...]. Tom. 1680. Vol. 3/2, Frankfurt am Main, 1680.

LEIBNITZ, Thomas. Die Musik der Kaiser im Spiegel der Wiener Hofmusikkapelle. In Spettacolo Barocco! Triumph des Theaters. Andrea Sommer-Mathis - Daniela Franke - Rudi Risatti (eds.). Wien: Michael Imhof Verlag, 2016.

MIKULEC, Jiří. Leopold I. Život a vláda barokniho Habsburka. Praha, Litomyšl: Paseka, 1997.

NAGEL, Johann Willibald - ZEIDLER, Jakob. Deutsch-österreichische Literaturgeschichte, Bd. 1. Wien: Fromme, 1899.

NĚMEČEK, Jan. Nástin české hudby XVIII. století. Praha: Státní nakladatelství krásné literatury, hudby a umění, 1955 .

NIUBÒ, Marc. Císařský dvưr v Praze v letech 1679-80 a oratorium o svatém Václavovi. Diploma thesis. Praha: FFUK, 2000.

NIUBÒ, Marc. Le cappelle imperiali e la stagione praghese 1679/80. In „Il nuovo Cario, il divin Orfeo. “Antonio Draghi da Rimini a Vienna. Emilio Sala - Davide Daolmi (eds.). Lucca: Lim, 2000.

NIUBÒ, Marc. Leopold I. a hudba císařského dvora v Praze v letech 1679-1680. In Barokni Praha - barokni Čechie 1620-1740: sborník príspěvků z vědecké konference o fenoménu baroka v Čechách, Praha, Anežský klášter a Clam-Gallasưv palác, 24.-27. zář́i 2001. Olga Fejtová et al. (eds.). Praha: Scriptorium, 2004. 
REZEK, Antonín. Paměti generála řádu křižovnického Jiřího Pospíchala z let 1661-1680. In Zprávy o zasedáni Králouské české společnosti nauk 1880. Praha: Královská česká společnost nauk, 1881.

ROMAGNOLI, Angela (ed.). Antonio Draghi: Jephte. Praha: Koniasch Latin Press, 2000.

ROMAGNOLI, Angela. Galline, „Specolazioni“ e pene d'amore ossia La patienza di Socrate con due mogli di Minato e Draghi. In „Il nuovo Cario, il divin Orfeo. “ Antonio Draghi da Rimini a Vienna. Emilio Sala - Davide Daolmi (eds.). Lucca: Lim, 2000.

SEHNAL, Jiří. Pobělohorská doba (1620-1740). In Hudba v českých dějinách: od středověku do nové doby. Jaromír Černý et al. (eds.). Praha: Horizont, 1983.

SEIFERT, Herbert. Die Oper am Wiener Kaiserhof im 17. Jahrhundert. Tutzing: Verlegt bei Hans Schneider, 1985.

SCHEITLER, Irmgard. Deutschsprachige Oratorienlibreti von den Anfangen bis 1703. In Beiträge zur Geschichte der Kirchenmusik. Ulrich Konrad (eds.), Bd. 12., München: Görres-Gesellschaft, 2005.

SLOUKA, Petr. Německojazyčné holdovací serenaty Johanna Heinricha Schmelzera. In Cantantibus organis: hudebni kultura raného novověku ve středoevropských souvislostech: ad honorem Jiř́ Sehnal. Brno: Moravská zemská knihovna v Brně, 2016.

SLOUKA, Petr. Hudebnědramatický provoz na dvoře císaře Leopolda I. In Koně v piškotech. Slaunosti na dvoře císaře Leopolda I. Kateřina Fajtlová - Miroslav Kindl (eds.). Olomouc: Muzeum umění Olomouc, 2017.

TAUBER, Oscar. Geschichte des Prager theaters. Von den anfängen des schauspielwesens bis auf die neueste zeit. Prag: K.K. Hofbuchdruckerei A. Haase, 1883.

TROLDA, Emilián. Česká církevní hudba v období generálbasu. Cyril, 1934, LX.

VOLEK, Tomislav. Die Bedeutung der italienischen Oper für das böhmische Barock. Mozart, die Italienische Oper des 18. Jahrhunderts und die musikalische Leben im Königreich Böhmen. Bd. II. Wien: Hollitzer Verlag, 2016.

WEILEN, Alexander von. Die vom Jahre 1629 bis zum Jahre 1740 am Wiener Hofe zur Aufführung gelangten Werke theatralischen Charakters und Oratorien. Wien: A. Hasse, 1901. 
